

\section{Abstract}

This article is the result of a study that seeks to understand the relationship between socio-economic conditions, health and active ageing. Behaviours related to active ageing in relation to health were identified as were the strategies used in active ageing and their determinants. A qualitative methodology was adopted in the form of semi-structured interviews. Data processing consisted of thematic content analysis in interviews. Two socio-economic groups of elderly Cape Verdean men and women composed the study sample. Both groups totalled 22 cases. Findings indicated that the socio-economic status interferes directly in the affairs of active ageing rather than health issues. In the higher socio-economic group, it was found that status determines active ageing rather than health issues.

Keywords: elderly; immigrants; health; active ageing; socio-economic groups; Cape Verdeans 


\title{
Health, Ageing Migrants and Care Strategies
}

\author{
B.Bäckström
}

\section{Introduction}

This paper seeks to understand the relation between health, ageing migrants, and strategies of care. Comparing two different socioeconomic groups, socioeconomic conditions were found to determine active aging sooner than health issues. ${ }^{1}$ In the group of a lower social position, the socio-economic conditions acts in parallel with health conditions and both determine the activities that older people develop. The results proposevthat elderly migrants are in general a healthy population with healthy behaviors and practices, which comes mainly from their culture of origin and not because of socio-economic factors. However, in terms of health care and prevention practices, there is a difference between social groups, as the habit of routine check-ups as a form of prevention and the use of health services play an important factor. This said, the majority of elderly migrants are unaware of social support services in that such access are facilitated through their respective social security contributions, not only in Portugal but also in countries of origin to which access is sometimes difficult or even impossible because lacking information.

Demographic transition and demographic ageing of the population in Europe and in Portugal are principal tendencies of society, which have pressured the health sector, its access, its use and the consequent availability of services.

In terms of migration flows to Portugal, there are both chronologically advanced and more recent flows. Within the category of senior migrants, there are those who only come to Portugal for medical reasons to profit from the social support network, which is invariably a result of family reunification. Others arrive under bilateral agreements and conventions between Portugal and their countries of origin (PSAC), these become regular users of the care given by the Portuguese National Health System (Estrela, 2009). When compared to the elderly Portuguese population, elderly migrants are in general a healthy population, with healthier behaviors and practices which mainly arise from their culture of origin and lifestyles, rather than socio-economic factors. In terms of health care and prevention practices, there is nevertheless a difference between social groups such as the habit of routine check-ups as a form of prevention and the use of health services as emergency treatment.

Migratory flows contribute towards the renewal of the Portuguese population with active ageing workers and births, but there is also, for the first time, the emergence of a historical migration group which arrived in the 1980s. This group, is composed of retirees and are mainly from Portuguese-Speaking African Countries.

Another sub-group is defined by migrants that have already arrived with an advanced age and reunited their family in Portugal for health reasons. This group also includes retired migrants from northern Europe and the United

${ }^{1}$ Due to genetic factors people age differently, irregardles of gender, family composition, residential situation, profession or country of origin. Both phenomena - ageing and migration - have been deeply studied, but their interaction has rarely been analysed and assessed.

Health, Ageing Migrants \& Care Strategies Volume 8, No. 2 (2015) | ISSN 2161-6590 (online) | DOI 10.5195/hcs.2015.207 | http://hcs.pitt.edu 
Kingdom who had moved to the Algarve, designated as lifestyle migrants. The present study estimates that 35 thousand old migrants currently reside in Portugual with access to the Health System and its concordant services.

Many migrants who arrive at their country of destination have plans to return to home. This has often been characterized as the "myth of return". This is applicable to migrants who have sought stay for reasons independents of lifestyle choices, and these live in a dual conflict: they feel foreign to a country where they have lived for three or four decades, but they also feel like strangers in their country of origin due to the passing of time. Consequently, the return envisagedprior to and upon arrival, remains all but an unproven myth for the majority.

Migrants can become so familiar and adapted to their 'new' home that they do not wish to undertake further change across continents, while others have descendants and feel that they are needed to take care of their grandchildren. In either case, networks have been built, sentiments established and a certain degree of life's comforts had and guaranteed. The offering of wellness and life quality in terms of access to better health care are reasons to stay, and along with demographic changes there are great health and epidemiologic transitions in parallel to such choice-driven trends.

It was only in 2010 that ageing of migration gained a certain degree of visibility on the political and scientific horizon in Portugal. These populations appeared for the first time, for example, in the second Plan for integration of Immigrants (2010-2013). In 2010, the study by Machado and Roldão (Machado, Rodão, 2010) as with that of Marques and Ciobanu (Marques, Ciobanu, 2012) in 2012 also served to highlight the role such migrants and active ageing play in the composition of the social, industrial and sectorial sphere. Likweise, a special issue of the 'Migrações' journal was also published in 2012 on Immigration and Active Ageing (Machado, 2012).

\section{Ageing, Migration \& Strategy}

The world population has more than tripled between the early and late 20th century, where seven billion were accounted for.

This increase, however, was not linear over time since population growth accelerated in the second half of the 20th century. According to the United Nations, it is estimated that by 2050, nine billion people will populate the earth's surface (Valente Rosa, Seabra, Santos, 2004). More specifically, it is in the elderly age group that a more significant increase is to be expected by 2050 where there may be 1.9 billion sixty-year-olds or older. The older seniors (80 and older) are noteworthy within this age group, which may reach 377 million in 2050 (Valente Rosa, Seabra, Santos, 2004).

There is no doubt that one of the greatest human accomplishments has been to live longer, and old age which used to be a privilege for the few - is now a common occurrence in middle to low developed nations. According to Fernandes (Fernandes, 2007; Fernandes, 2008; Fernandes, 2005, Fernandes, 2001, Fernandes, 2007b), in addition to the global relationship between demographic growth and economic development, demographic transition leads to two outcomes: (1) the ageing of demographic structures and, (2) migration. One of the results of such dynamics is the growing search for healthcare services and the pressure on service capacity. The elderly require more healthcare services, frequent hospital admissions, and more time in bed in relation to other age groups. The elderly usually have chronic and multiple diseases, which last for many years and require constant treatment, permanent care, continuous medication, and regular checkups (Lima Costa, Veras, 2003).

Health, Ageing Migrants \& Care Strategies Volume 8, No. 2 (2015) | ISSN 2161-6590 (online) | DOI 10.5195/hcs.2015.207| http://hcs.pitt.edu 


\section{Active ageing}

The active ageing concept is, according to the World Health Organisation (WHO, 2002; WHO, 2005), the process of optimizing opportunities for health, participation and security in order to enhance quality of life as people age.

The word "active" refers to continuing participation in social, economic, cultural, spiritual and civic affairs, and not just the ability to be physically active or to participate in the labour force. Participation in the labour force may indeed be due to economic needs, while labour may be an obligation that arises from a financial need, as well as the necessity for the elderly to continue working, particularly those belonging to lower social classes, which may not be the same thing as active ageing, since it does not relate to pleasure or a choice but an obligation and necessity.having to work at an advanced age is a different type of active ageing, which is forced and related to the work itself instead of leisure. Bankruptcy of the welfare state and the financial crisis will generate a significant swell in the number of advanced age workers.

Ageing should nevertheless be a positive experience with the best quality of life possible. The ethos of this study is rooted in the belief that the active ageing concept may also include work - a professional activity - as long as that activity is an elective choice (sooner than an imposed necessity) and will contribute towards the elderly person's happiness and well-being. When work is carried out as an obligation and necessity, without a positive contribution throughout the ageing process, then it is considered the anithesis of active ageing.

The behavioral determinants of active ageing throughout life - particularly the adoption of healthier life styles and a pro-active attitude in promoting self-care - are considered essential for a healthier and longer life. A gender specific approach should be considered in light of the biological differences and their social roles, which shape the identity of each gender throughout life history. A gender approach will enable the differences regarding social and health requirements in men and women to be understood, based on the different ways in which both live and age. Culture should also be respected, which comprises all people and populations sharpening our ageing process, since it influences all other factors determining active ageing (Assis, 2005).

Cultural values and tradition also indelibly determine the way a society treats the elderly and the ageing process. For example, in many Asian countries, the cultural rule is to value extended families and life together as a family in homes with several generations, where the elderly person is particularly revered, since the latter transmits the 'family history'. Cultural factors are also an influence in the search for healthier behaviors. Culture and gender are transversal determinants, which are an influence on other active ageing determinants by interfering not only in the way generations relate with each other, but also in health and disease-related behavior. In societies, for example, where it is culturally normal to relate ageing with the fatality of diseases inherent to this age group, early prevention and detection measures are usually not considered as important or prioritized, where proper health care for this age group is neglected and resources are channeled to the adult and productive population. The elderly person may in turn become more or less vulnerable depending on several factors, which are not entirely independent from each other (Paúl, 2005).

Maintenance of social roles and both formal and informal social networks are fundamental determinants in active and healthy ageing. The elderly are motivated and active when their social roles remain the same. An example of this is fostering active citizenship and contributing towards family decision-making.

\section{Ageing support programmes and policies}

Ageing has been the focus of political and scientific discourse: the European Union has promoted political guidelines as to decrease negative ageing impact. A great part of the elderly population is facing the risk of being socially excluded and poor due to age. Age-related vulnerability is a concern in European countries with social 
protection systems where so-called 'informal' traditional solidarity structures do not generally prevail, such as family and neighbors. New problems arise within this global ageing process where the welfare state crisis undermines the effectiveness of government policies for social protection, thus compromising the system's financial sustainability, and viability.

In Portugal, there have lengthy discussions on public policies are yet to be had to an effective extent. As a result it can be argued that Portugal will present the same ageing levels as its European neighbours. Certain political initiatives of an institutional nature have been witnessed, from the Comissão Nacional para a Politica da Terceira Idade (Portuguese Committee for Elderly Policies); the State Secretariat for Family Affairs, and the Observatory and Consultative Council for Family Affairs (Veloso, 2008). The National Health Programme for the Elderly - established by the Health Division - reflects a strategy based on UN principles: independence, participation, self-fulfilment, and dignity for the elderly. In Portugal, external and internal migrations are certainly important in the evolution of demographic structures, and while external migrations may slow down the global ageing process they may also speed it up.

In terms of immigrant health policies, immigrants in Portugal receive medical attention in a health centre or hospital. This right is provisioned by Order No. 25 360/2001 (Bäckström, 2009; Bäckström, 2011, Bäckström, 2012, Bäckström, Carvalho, Inglês, 2009, Pussetti et al, 2009). In addition, Portuguese-speaking African countries have also signed cooperation agreements with Portugal for medical assistance in order to cover citizens of African countries that have Portuguese as their official language. Medical assistance in Portugal is one of the strategic plinths in the strengthening of international cooperation within health (DGS, 2004).

\section{Immigrants in Portugal and Ageing}

By the closure of 2010, foreigners residing in Portugal ammounted to 445 262. According to the 2010 SEF (Immigration and Border Control) report, the number of immigrants residing in Portugal decreased in comparison to the previous year, thus breaking the continuity in the growth of Portuguese foreign communities. Of this sample, Brazil, Ukraine, Cape Verde, Romania, Angola, and Guinea-Bissau composed the top-tier of migrant populations. Brazil was the most represented foreign community totalling 119363 residents. $^{2}$ The Ukraine was the second (49 505), followed by Cape Verde (43 979), Romania (36 830), Angola (23 494) and Guinea-Bissau (19 817 citizens). ${ }^{1}$ According to INE (Statistics Portugal, INE, 2010), out of the immigrant population residing in Portugal on December 31st, 2010 (445 262), 85.47\% were of working age (between 15 and 64), 10.21\% were in their youth (younger than $15)$ and $4.32 \%$ were elderly (65 and older).

There are different immigrant categories in Portugal, and as there is diversity in immigration, there is also diversity among senior immigrants. There are labour-bound immigrants who arrived in search of a better life, and in the meantime have aged in their place of destination - most of them from former Portuguese colonies in Africa. Immigrant citizens from northern Europe who arrived in Portugal post-reformation era have also settled; just as Portuguese emigrants who returned to their country of origin after a life-time working abroad (returnees) - -, and senior immigrants who join their families (usually individuals who depend on their emigrant offspring and follow their footsteps or those of family members in order to join them or to receive medical treatment). Data suggest a specific family reunification process, where older and inactive immigrants join their families in Portugal in search of

\footnotetext{
2 According to the 2010 Pordata database, the overall number of legally resident foreigners was 443055 . Brazil amounted to 119 195, Ukraine 49 487, Cape Verde 43 510, Angola 23 233, and Guinea-Bissau 19304 (Pordata, 2011). Data published in Pordata only apply to foreigners with residence
} 
better elderly care conditions (Marques e Ciobanu, 2012). Each category is distinguished on a socio-economic, gender, occupation, citizenship, and participative basis.

Regarding migration flows, these also vary, as well as earlier or more recent trends on a chronological scale. For example, the senior immigrant category also includes those who only arrive in Portugal for medical reasons and take advantage of the social support here for health issues, which is a result of family reunification. Others also arrive under bilateral health agreements or arrangements signed by the Portuguese government and their countries of origin. Thus, they become regular or potential users of the Portuguese Health Care System (Estrela, 2009). Immigrants from Cape Verde have the highest number of elderly people, who were the earlier group of immigrants to arrive in Portugal (Machado, Roldão, 2010). All other immigrants are more recent and only became statistically significant from 19741975; they also include a lower number of senior citizens. According to Machado, 1310 senior African citizens arrived between 2001 and 2005, which increased approximately 10\% in relation to 2001 (13 070). In Portugal, the ageing of the population is a worrisome trend and reality; despite the ageing of the immigrant population still being a residual phenomenon (INE, 2010). In most (eight) foreign populations - Romanian, Russian, Moldovan, Guinean, Angolan, São Toméan, Chinese and French - the number of old people does not reach 1/5 of the number of youths. On the other hand, the citizens from Spain and the UK show higher ageing levels than those of the Portuguese and foreign population in Portugal. Although ageing of the overall population residing in Portugal was quite significant in the 90s, it would have been greater if it were not for foreign numbers, which show more youth of the active age (Valente Rosa, Seabra, Santos, 2004).

\section{Social support networks}

Social support networks should strengthen all affective and social bonds that have grown and been cultivated throughout life, this being one of the most relevant factors in the quality of life of the elderly and their emotional balance. Senior immigrants who reside with their family are better protected for their main support comes from members of the social networks to which they belong. These networks are generally created within foster communities whilst family and those closest appear as fundamental resources to the elderly among immigrant communities: a family is many times the major place for intergenerational exchange, care, and support. Informal family solidarity is a powerful source of mutual aid and exchange, which counterbalance formal solidarity. The types of aid and care among family members meet the basic requirements for difficult time, money, and space management, which are not overcome by public aid. We may assume that senior immigrants do not resort to any of these types of care - domestic support, nursing homes or day-care institutions -, which are ensured by the women in the family. Women ensure care and an ongoing presence in services, goods, and material support. In the case of African immigrants in Portugal, the network of family and friends that already exists in the host country has been a decisive factor in choosing a destination. There is a tendency for immigrant groups to live as a geographical cluster and in ghettos. Most ethnic minority communities choose to stay together, often for social reasons, but also due to financial needs and fear of discrimination. This neighbourhood concentration may be a positive experience in the short-term, since it favours access to support that is offered by members of their own cultural community (Massé, 1995).

After research carried out on immigrants residing in Lisbon (Bäckström B, et al 2011), studies were able to distinguish the very different ways in which the African elderly were treated: they are raised to never abandon their parents and care for them until death. They remain at home because there is always a family member to care for: inside the house of a child there must always be a place for the elderly. In the African culture, the elderly die beside their offspring and are never put in homes. Consequently, the desire to return to the country of origin and age there is due to a strict connection between the elderly and their family. They prefer to die in their country of origin. 


\section{Methods}

This analysis aims at understanding active ageing and its relationship with health looking at two different socio-economic groups of elderly immigrants from Cape Verde, their strategies and determinants. Two groups were established for analysis considering the internal social heterogeneity among social classes within the Cape Verdean community, where the place of residence, educational levels, professional activity, and the economic situation of first generation immigrants from Cape Verde living in the Lisbon area are used as variables. In order to make identification easier, both groups were designated as (1) a People's Group and (2) an Elite Group. The most common factor of analysis was that the groups should be made up of first generation Cape Verdeans born and raised in Cape Verde until the age of 17. The method of respondent recruitment was via Association located in Lisbon and which represent Cape Verdean citizens. Meetings were scheduled with the head of the respective Association; research was explained and potential cases were requested for our sample. A qualitative approach by means of semi-structured interviews was adopted for collation. Interviews were conducted by the researcher who recorded dialogue at the respondent home and at times at the migrant Association located in surrounding neighborhoods. Data processing consisted of thematic content analysis and identification of differences and similarities between and within each sub-group.

Confidentiality and anonymity was in all cases upheld and preserved. Twenty-two elderly cases were analysed: seven men and five women within the Elite Group, and five men and five women within the People's Group. Respondent age ranged from 56 to 81, with an average age of 65.9.

The underlying motive was to glean information on activity and occupation, regardless of health status. The respondent sample has relevant characteristics: people were chosen by their age (generation), gender, and socio economical characteristics. With this, the influence of such variables on health and activity could be analysed as well as assessing whether health status holds greater importance than socio-economical status in terms of "active" ageing.

Our present study provides a snapshot of research findings in order to support further enquiry into the relation between migration population (and the demographic effects of such population movement); ageing and the consequent user behaviours of health services.

\section{Results}

The different factors and variables related with active ageing as well as the "activity" that determine active ageing were assimilated into an analysis of discourse content. The use of active ageing strategies and the determinants of such activity, as well as welfare and health generators featured as important components to analysis with results thematically categorised: respondents with ailments; respondents that are still working and the activity of respondents retirees. For each theme routines, regular activities, lifestyles, and preferred occupations were analysed.

\section{Sickness and Disease status}

The greater part of the statements analysed for this particular group were from individuals of what we have deemed the "popular group" where it was seen that women voice increased complaint about health issues than men:

I have a heart condition and I've been to Hospital lately with $450 \mathrm{mg}$ diabetes. I suffer going to the doctor because I can't walk long distances alone since I might fall down anywhere [...] Now my home is the church and my own home. My only concern in life is health [...] My biggest wish is for money and health [...] (D, male, 1930); 
I'm limited because of my back [...] (A, male, 1953).

I am always sick. I have diabetes, bronchi issues, I'm always in Hospital [...] whenever I have a problem my granddaughter takes me to Hospital because I have thyroid problems. I don't work, I'm 65 but I don't work [...] I stay here, walking slowly. I don't walk much because my foot is swollen and my back aches. I don't go out much. Most of the time, I go to the doctor, if I have money I will take a taxi to the bus stop, which is very far, and then I will take another taxi back home. I watch TV; I watch my favourite soap operas until late [...] I go to bed at around 1 a.m. Sometimes I wake up at 11 a.m. with nothing to do' (T, female, 1938).

Regarding the elderly women within the People's Group, some expressed that they held resentment towards their life either owing to ailment or the loss of family members.

In the group we have named the Elite Group, three men and one woman identified themselves as chronically ill:

The problem is learning to live with the disease and its psychological aspect. This disease reduced some of my life $[\ldots]$ (A, male, 1946)'

[...] I have some mobility; therefore I am able to maintain a certain quality of life within those setbacks and adversities (A, Female, 1940)'.

\section{Active Life Status}

Work

From the Elite Group four respondents are still working, two men and two women. They consider themselves professionally active. The respondents are also active in social and cultural activities during their more leisurely moments. One respondent, a healthy, active lawyer with no financial constraints regularly "practise[s] sports, golf and hiking" and maintains a strong connection with Cape Verde:

I continue to appreciate Cape Verdean cuisine and music, my friends over here [...] which I can say I have a great $[. .$.$] a large number of Portuguese friends, but a great number of my good friends are from Cape Verde'$ (C, male, 1932).

From the People's Group those respondents that continue to work say their health is good enough in order to fulfil the demands of their respective professions. Three woman are working in the cleaning and trade business and consider their respective health status sufficient for work. In contrast the Elite Group identified the lack of free time and in terms of leisure and weekends the same expression was used: "My free time, look [...] work and home. I have to take care of the household, tidy up, do the washing [...]"

Respondents are still working are for two reasons: (1) because they are yet to reach retirement age (65) and/or (2) they have liberal and religious vocations. Another situation is the case of people that need to work for financial reasons in order to support old age. Such cases composed the lower socio economical group. 


\section{Active retired}

From the People's Group, men who declared themselves busy and active while retired, stated that on occassion their health suffers. Despite sporadic dclines the respondents nevertheless lead an active life, through gardening for example, or by working as an Association leader. L (male, 1947) is still active with a garden to keep him busy on weekends. He chooses to do it out of pleasure, but he also combines business with pleasure, since it produces vegetables to be consumed by his family or sold in the local market.

In the Elite Group a more active lifestyle was declared, yet one patterened with some health problems. The respondents are retired but nevertheless very active, for example as chairman of a Cape Verdean Association, or engaged in professional activity (officially retired but still maintaining a profession), spending their time between Portugal and Cape Verde:

I often travel to Cape Verde to take care of things and because I enjoy being there. I am part of a congress of Cape Verdeans of the Diaspora: leader. I am responsible for the Cape Verdean space, which includes the solidarity movement for Cape Verde, books I am reading, and music that is $100 \%$ from Cape Verde (L, male, 1947)

The active and socially integrated lives of $\mathrm{M}$ (female, 1943) and P (female, 1943) are two examples of active ageing. $\mathrm{M}$ is currently retired and studies Art History as well as Psychology at University. She lives well, feels very good and healthy, enjoys the outdoors, practises water aerobics, enjoys going for walks, and reading. She also maintains close ties with her country and fellow countrymen, as well as belonging to a Cape Verde Association of Former Secondary Students:

I go to that Association every week and meet fellow countrymen [....] I do not have much time, my days should be 48 hours long (laughter) [...] I care about my happiness and try to help others; that is my motto'. 'I have to be healthy to maintain this quality of life, if it were not for my health I could not be doing what I do. In order not to get sick, I keep myself occupied, eat well [...] (M, female, 1943)'.

$\mathrm{P}$ (female, 1943) is very much in touch with the arts and general culture. She is a singer, story-teller, writer, and also an Association leader. It was seen that women are retired but with a very active lifestyle and taking extreme care of their health. Nowadays, they prefer alternative and homeopathic medicine as well as acupuncture.

There were no substantial variances observed in gender with the exception of men expressing greater concern with employment and finances. Women, were ultimately concerned with their health.

\section{Conclusion}

Healthier senior citizens are in physical shape for active and socially integrated ageing, while sick and more debilitated senior citizens tend to become more inactive and isolated, as in Machado [4]. If at first we thought we would find differences per gender and generation regarding health, we can now assure that these differences take place mostly between socioeconomic groups (Popular and Elite), although they belong to the same gender (either male or female).

The Black Report (Towsend, Black, 1992) names one of the reasons for these differences regarding health as behaviour and culture, which includes class differences in terms of destructive or healthy behaviours, depending on individual choices. Food preferences, drug consumption - such as cigarettes and alcohol -, leisure time, and

preventive medical services - such as immunisation, contraception, and prenatal care - are examples that vary depending on the social group and may contribute towards class differences in health. Eating diets or habits are 
influenced by cultural preferences as well as available finances. Williams et al (Williams et al, 2000) met a disparity between the way people express themselves in public regarding certain types of health behaviour and private perceptions guiding their individual actions. They indicate the existence of a relationship between the social structure and a notion of health, eating habits, and physical exercise in lower proportions. This difference can be explained by fewer material conditions rather than accessibility issues.

A very common habit to all Cape Verdeans is exercise. Many of the individuals interviewed stated that they used to exercise more in Cape Verde than they did after moving to Portugal. It becomes clear that exercising is mostly a male activity whilst the female gender practising sports belongs to the Elite Group.

Most Elite Group elements - such as R (male, 1941), A (female, 1940), M (female, 1943), and P (female, 1943) - confess to eating correctly by avoiding fats, fried products and sugar, replacing them with grilled, cooked, and vegetable-based products.

The difference between men and women in the People's Group is mainly established when it comes to "free time" or leisure time, since women usually take advantage of such time to look after the house or they simply do not have any outdoor activities. Leisure time also seems to be associated with social status. Reading, going to the cinema, listening to music, spending time with friends, talking, and going for walks are activities referred by people belonging to the Elite Group.

Considering the number of analysed variables - particularly in terms of health care and prevention, (diet habits, cigarettes and alcohol, physical exercise and leisure time) - a healthy population with a healthy behaviour and lifestyle is a condition of culture sooner than socio-economic factors. With this, the elderly live their condition in very different ways, even when living in the same society: there may be common ageing parameters, but there are also different social environments, family environments, social networks, leisure times, medical conditions, and socioeconomic conditions.

The Elite Group included the subgroup of those financially sound and who remain active in terms of free time, in terms of profession, and as association leaders. They are financially stable with busy lives and live surrounded by people. They consider themselves as healthy, and even those less healthy are socially integrated and active. Four people declared they have health problems in the Elite Group, but are active. There is only one situation where, for health reasons, the person in question is not very active, thus more isolated. The association leaders are intensely involved in association activities, although three of them have health issues. Here we have intense bonding and social life of individuals that are frequently seen with their fellow countrymen and being members of the association. We also find self-employed who lives between Portugal and Cape Verde and often travels from one country to the other. This group includes persons who are still professionally active.

This Elite Group also includes B (male, 1945) who is less healthy and more limited, but remains active as an option, as well as pleasure because he likes being busy and doing what he loves.

Socio-economic conditions along with health contribute towards more or less active ageing, however, in the Elite Group, the socio-economic conditions determine that active ageing instead of health issues (for example, although she is not healthy, A is very busy and successful on a personal basis).

In the case of People's Group, socio-economic conditions play a role in active ageing along with health conditions determining the activities carried out by the elderly, which are based on their professional category and education level. Some, considered less healthy, among those who are incapacitated are more dependent on the others and more limited. They don't have any activities besides the church and being home and are socially isolated and inactive. Others complain of health issues, financial difficulties, and life concerns. But in some cases, among the less 
healthier people don't feel that disables them, keeping active, carrying out a few leisure activities with the family or as a committed association leader, although health problems.

Working at an old age may be interpreted as active ageing at times. However, in other cases it only means socio-economic vulnerability that is being forced to work up to a very advanced age since the only alternative will be a retirement pension that will be too low for acceptable living conditions. The African elderly usually work until later in life than the Portuguese elderly, but they struggle to do it and at times without the necessary health, since they usually work in manual professions, which are physically demanding.

Women in the People's Group work in cleaning until later than men, with respect to age, even the older ones. Three out of the five women still work regularly. Only one claims to be in good health. The men are unemployed or retired; only one has a job, while the other is retired and keeps himself busy as an association leader.

These are two models of interpretation for the elderly to remain in the labour market: financial needs and active ageing, which overshadows financial needs, depending on which socio-economic group the individuals are a part of. According to Machado [4], health conditions are a part of the ageing context, but these particularly interfere in the activities of the individuals within the People's Group in light of the financial issues.

Being active while being retired, even if they have not a good health is referred by two men from the popular group. In the Elite Group four people said they have a more active lifestyle, even with some health problems.

From the crossing between health (being healthy/being sick) and socio-economic conditions (Elite Group/ People's Group) - which consider on one side poor ageing against comfortable ageing -, we reach types of active and socially integrated ageing and inactive and socially isolated ageing. More health contributes towards active and socially integrated ageing, while less health contributes towards inactive and socially isolated ageing, as in Machado (Machado, Roldão, 2010).

In the future, ageing-oriented public policies are to be grasped, particularly those including elderly migrants, paying special attention to eventual loopholes. The following questions need to be discussed: Which public policies take into account the elderly migrants? What are the specific needs of elderly migrants and under what terms is their satisfaction socially legitimate? What are the local and national institutions for dealing with migrant ageing? What is the connection (if there is one) between formal and informal support? There are elderly immigrants who are completely unaware of their rights. The Plan for integration of Immigrants (PII II) (Acidi, 2010) has put its faith in fighting socioeconomic vulnerability of the elderly immigrants by broadcasting all available institutional support. An intervention with the elderly immigrants is a novelty due to this being a population that many times face double social exclusion. Such intervention dedicated to measures related to the elderly immigrants is fighting socio-economic vulnerability by broadcasting available institutional answers ignored by most, social support, rights arising from Social Security contributions and how to access them - not only in Portugal but also in the country of origin and the European Union -, which is many times difficult or impossible due to ignorance of such access (Acidi, 2010). Immigrants are still mostly of a young and active age. Still, in future, this intervention shall provide the elderly immigrants - the number of which is increasing - with access to useful information regarding their rights. Many are unaware of their rights and they could even become Portuguese citizens, as an example, because they may meet the necessary conditions but have never tried to do so, although it may enable them access to social benefit and support in spite of the current crisis and gradual disappearance of the welfare state and social state, less protection, the end of retirement and retirement pensions for future generations as well as those that are currently active. It is very important to analyse in order to act so that we may realise what can and must be done in light of these new stakes. 


\section{References}

ACIDI , Alto Comissariado para a Imigração e o Diálogo Intercultural (2010), II Plano para a Integração dos Imigrantes (2010-2013) - Resolução do Conselho de Ministros n. ${ }^{\circ} 74 / 2010$; I Plano para a Integração dos Imigrantes - Resolução do Conselho de Ministros n. ${ }^{\circ}$ 63-A/2007.

Assis M. (2005) 'Envelhecimento activo e promoção da saúde: Reflexão para as acções educativas com idosos'. Revista APS, v.8, n.1.

Bäckström B, Castro-Pereira S, Campos R, Sardinha J e Moreira D, (2011) Histórias Biográficas de Imigrantes em Lisboa, Universidade Aberta: CEMRI, Lisboa

Bäckström B.(2012), 'Envelhecimento ativo e saúde num estudo de caso com idosos imigrantes', in MACHADO, Fernando Luís (org.), Revista Migrações - Número Temático Imigração e Envelhecimento Ativo, Abril 2012, n. ${ }^{\circ}$ 10, Lisboa: A CIDI, pp. 103-126.

Bäckström B. (2011) 'Comportamentos de saúde e doença numa comunidade Cabo-Verdiana em Lisboa'. Saude soc., São Paulo, v. 20, n. 3, setembro.

Bäckström, B. (2009) Saúde e Imigrantes: As representações e as práticas sobre a saúde e a doença na comunidade cabo-verdiana em Lisboa: Observatório da Imigração, colecção teses nº 24, Setembro.

Bäckström B., Carvalho A., Inglês U. (2009) 'A nova imigração e os problemas de saúde em Portugal - O Gabinete de Saúde do Cnai enquanto um observatório para o estudo da saúde dos migrantes em Portugal'. Revista Migrações, $\mathrm{n}^{\circ}$ 4, Abril 2009, Observatório da Imigração.

Direcção-Geral da Saúde, Circular Normativa (2004), Programa Nacional para a Saúde das Pessoas Idosas N: 13/DGCG.

Estrela P. (2009) 'A Saúde dos Imigrantes em Portugal', Revista Portuguesa de Clínica Geral 45-55, Dossier Multiculturalidade.

Fernandes A. (2008) Questões Demográficas, Demografia e Sociologia da População Edições Colibri.

Fernandes A. (2007) 'Determinantes da mortalidade e da longevidade: Portugal numa perspectiva europeia (UE15, 1991-2001)’, Análise Social, vol. XLII (183).

Fernandes A. (2005) ‘Envelhecimento e Saúde’, Revista Portuguesa de Saúde Pública, vol. 23, n. 2, Julho/Dezembro

Fernandes, A. (2001) 'Velhice, solidariedades familiares e política social: itinerário de pesquisa em torno do aumento da esperança de vida'. Sociologia, Problemas e Práticas, set., no.36, p.39-52.

Fernandes, A. (2007b) Dossier Fórum Sociológico, edição nº 17 (II Série).

Instituto Nacional de Estatística. Estatistícas Demográficas, 2010. www.ine.pt

Lima-Costa, Maria Fernanda and Veras, Renato (2003). 'Saúde pública e envelhecimento'. Cad. Saúde Pública, vol.19, n.3, pp. 700-701.

Machado, F.L., Roldão, C. (2010) Imigrantes Idosos, Uma Nova Face da Imigração em Portugal. Lisboa: Observatório da Imigração, colecção estudos 39.

Machado, Fernando Luís (org.), Revista Migrações - Número Temático Imigração e Envelhecimento Ativo, Abril 2012, n. ${ }^{\circ}$ 10, Lisboa: A CIDI, pp. 103-126. 
Marques, M.M. e Ciobanu, R.O. (2012), Migrantes Idosos em Portugal, Cascais: Princípia.

Massé, R. (1995) Culture et santé publique. Gaëtan Morin Éditeur, Montréal.

Paúl C., (2005) 'Envelhecimento activo e redes de suporte social', Revista Sociologia, Porto: Faculdade de Letras.

Pussetti C. (coord.), Ferreira J, Lechner E, Santinho C. (2009). Migrantes e Saúde Mental. A Construção da Competência Cultural, Lisboa: Observatório da Imigração, colecção estudos 33.

Williams, S J.; Gabe, Jonathan; Calnan, Michael (ed.) (2000) - Health, medicine and society: key theories, future agendas. - London; New York : Routledge.

World Health Organisation WHO (2002). Active Ageing, A Policy Framework. A contribution of the WHO to the Second United Nations World Assembly on Ageing, Madrid, Spain.

World Health Organisation WHO (2005), Envelhecimento ativo: uma política de saúde / World Health Organisation; tradução de Suzana Gontijo. - Brasília: Organização Pan-Americana da Saúde.

Towsend P., Black D. (1992) Inequalities in health: the Black Report. Penguin, London.

Valente Rosa, M.J., de Seabra, H., Santos, T. (2004) Contributos dos ‘imigrantes’ na demografia portuguesa. O papel das populações de nacionalidade estrangeira. Lisboa: Observatório da Imigração, colecção estudos 4.

Veloso, E. (2008) 'A análise da Política da Terceira Idade em Portugal, de 1976 a 2002', Actas do VI Congresso Português de Sociologia, Lisboa 2008. 